\title{
The effects of dietary cholecalciferol and 1a-hydroxycholecalciferol levels in a calcium- and phosphorus-deficient diet on growth performance and tibia quality of growing broilers
}

\author{
J.C. Han ${ }^{1,6}$, H.X. Qu', J.Q. Wang' ${ }^{2}$, J.H. Yao ${ }^{3}$, C.M. Zhang', G.L. Yang ${ }^{1}$, Y.H. Cheng ${ }^{4}$ and X.S. Dong \\ ${ }^{1}$ Shangqiu Normal University, Institute of Animal Nutrition and Animal Genetics, College of Life Science, \\ Shangqiu 476000, P.R. China \\ 2 Shenyang Agricultural University, College of Science and Technology, \\ Shenyang 113122, P.R. China \\ ${ }^{3}$ Northwest A\&F University, College of Animal Science and Technology, \\ Yangling 712100, P.R. China \\ ${ }^{4}$ I-Lan University, Department of Biotechnology and Animal Science, I-Lan 26047, Taiwan, ROC \\ ${ }^{5}$ Taizhou Healtech Chemical Co., Ltd., Taizhou 318000, P.R. China
}

KEY WORDS: 1a-hydroxycholecalciferol, cholecalciferol, growth, tibia, potency, broiler

Received: 29 February 2012

Revised: 23 April 2013

Accepted: 13 June 2013

${ }^{6}$ Corresponding author: e-mail: j.c.han@hotmail.com

\begin{abstract}
This study aims to evaluate the effects of cholecalciferol (vitamin $\mathrm{D}_{3}, 0,5,10,25,50,100,250,500$, and $1000 \mu \mathrm{g} \cdot \mathrm{kg}^{-1}$ ) and $1 \alpha$-hydroxycholecalciferol $\left(1 \alpha-\mathrm{OH} \mathrm{D}_{3}, 0,2.5\right.$, and $\left.5 \mu \mathrm{g} \cdot \mathrm{kg}^{-1}\right)$ on growth performance and tibia quality and to compare the relative potency of $1 \alpha-\mathrm{OH} \mathrm{D}_{3}$ to vitamin $\mathrm{D}_{3}$ in 1- to 21-day-old female broilers fed a calcium (Ca)- and phosphorus (P)-deficient diet. The basal diet contained $0.50 \% \mathrm{Ca}, 0.25 \%$ non-phytate phosphorus (NPP) and was not supplemented with vitamin $\mathrm{D}_{3}$, whereas the control diet contained $1.00 \% \mathrm{Ca}, 0.45 \% \mathrm{NPP}$, and $25 \mu \mathrm{g} \cdot \mathrm{kg}^{-1}$ vitamin $\mathrm{D}_{3}$. Dietary vitamin $\mathrm{D}_{3}$ levels significantly affected body weight gain (BWG), feed intake ( $\left.\mathrm{FI}\right)$, serum $\mathrm{Ca}$ and tibia parameters. The addition of $5 \mu \mathrm{g} \cdot \mathrm{kg}^{-1} 1 \alpha-\mathrm{OH} \mathrm{D}_{3}$ resulted in greater BWG, FI, and serum $\mathrm{Ca}$ as well as tibia ash weight and content, breaking strength, and $\mathrm{Ca}$ and $\mathrm{P}$ contents, compared with the birds fed the basal diet. Using BWG, serum $\mathrm{Ca}$, tibia ash weight and content, and tibia $\mathrm{Ca}$ and $\mathrm{P}$ content as the criteria, the vitamin $D_{3}$ requirements of 1 - to 21 -day-old broilers fed Ca- and P-deficient diets were 64.0, 16.2, 173.0, 65.1, 33.1 and $30.0 \mu \mathrm{g} \cdot \mathrm{kg}^{-1}$, and the relative potencies of $1 \alpha-\mathrm{OH} \mathrm{D}_{3}$ to vitamin $\mathrm{D}_{3}$ were $5.03,2.19,18.00$, $5.14,4.09$ and 3.33, respectively. These data indicate that high levels of vitamin $D_{3}$ can spare the use of $P$ in broiler diets and that the potency of $1 \alpha-O H D_{3}$ is higher than that of vitamin $D_{3}$.
\end{abstract}

\section{Introduction}

In a basal diet with low levels of calcium $(\mathrm{Ca}$, $0.64 \%$ ) and total phosphorus (tP, $0.42 \%$ ), 8- to 20-day-old broilers that were fed $1250 \mu \mathrm{g} \cdot \mathrm{kg}^{-1}$ of cholecalciferol (vitamin $\mathrm{D}_{3}$ ) achieved greater body weight gain (BWG) and tibia ash content than birds fed $37.5 \mu \mathrm{g} \cdot \mathrm{kg}^{-1}$ of vitamin $\mathrm{D}_{3}$ (Baker et al., 1998). On the other hand, chickens fed $\mathrm{Ca}$ - and $\mathrm{P}$-adequate diets $(1.00 \% \mathrm{Ca}, 0.77 \% \mathrm{tP})$ with $5 \mu \mathrm{g} \cdot \mathrm{kg}^{-1}$ of vitamin $\mathrm{D}_{3}$ exhibited BWG and bone ash values as high as those of chickens that received 30 and 1250 $\mu \mathrm{g} \cdot \mathrm{kg}^{-1}$ vitamin $\mathrm{D}_{3}$ (Baker et al., 1998). These results indicate that broilers require less vitamin $\mathrm{D}_{3}$ 
when their diet contains adequate $\mathrm{Ca}$ and $\mathrm{P}$. When the broilers were fed sufficient $\mathrm{Ca}$ and $\mathrm{P}$, their body weight and tibia breaking strength were maximized on day 14 with $250 \mu \mathrm{g} \cdot \mathrm{kg}^{-1}$ of vitamin $\mathrm{D}_{3}$, tibia ash was maximized with $125 \mu \mathrm{g} \cdot \mathrm{kg}^{-1}$ vitamin $\mathrm{D}_{3}$ (Whitehead et al., 2004), and bone area, thicknes, and mineral content increased with $250 \mu \mathrm{g} \cdot \mathrm{kg}^{-1}$ vitamin $\mathrm{D}_{3}$ (Kim et al., 2011). With growth improvement, broilers need more vitamin $\mathrm{D}$ for bone development and strength. In addition, the environmental pollution caused by $\mathrm{P}$ in poultry production requires the increasing attention of animal nutritionists. Qian et al. (1997) found that dietary Ca to tP ratios ranging from 1.1 to 1.4 are critical for the efficient use of phytase and vitamin $\mathrm{D}_{3}$ in improving the utilization of phytate P. Rao et al. (2006) reported that in a basal diet with $0.50 \% \mathrm{Ca}$ and $0.25 \%$ of non-phytate phosphorus (NPP), the addition of $90 \mu \mathrm{g} \cdot \mathrm{kg}^{-1}$ vitamin $\mathrm{D}_{3}$ maintains growth performance and bone mineralization in broilers. These data suggest that the addition of high levels of vitamin $\mathrm{D}_{3}$ can spare the use of $\mathrm{P}$ in broiler diets with an appropriate $\mathrm{Ca}$ to $\mathrm{P}$ ratio. The vitamin $D_{3}$ requirement of broilers for growth and bone quality in $\mathrm{Ca}$ - and $\mathrm{P}$-sub-adequate diets is unclear, however.

The compounds $1 \alpha$-hydroxycholecalciferol $\left(1 \alpha-\mathrm{OH} \mathrm{D}_{3}\right)$ and 25-hydroxycholecalciferol (25$\mathrm{OH} \mathrm{D}_{3}$ ) are vitamin D metabolites. Recently, 25$\mathrm{OH} \mathrm{D}_{3}$ has been approved for use in feed for fattening chickens, laying hens and turkeys in Europe. It is possible that $1 \alpha-\mathrm{OH} \mathrm{D}_{3}$ will become a feed additive in the future. Kasim and Edwards (2000) evaluated the effects of different vitamin $\mathrm{D}_{3}$ sources on growth and tibia ash using broiler chickens fed Caand $\mathrm{P}$-adequate diets $(1.0 \% \mathrm{Ca}, 0.7 \% \mathrm{tP})$. In other studies, similar basal diets with sufficient $\mathrm{Ca}$ and $\mathrm{P}$ were used to compare the efficacy of vitamin $\mathrm{D}_{3}$ with that of $1 \alpha-\mathrm{OH} \mathrm{D}$ (Edwards et al., 2002) and that of vitamin $\mathrm{D}_{3}$ with that of $25-\mathrm{OH} \mathrm{D}_{3}$ (Yarger et al., 1995; Fritts and Waldroup, 2003). Vitamin $\mathrm{D}_{3}$ (Qian et al., 1997) and $1 \alpha-\mathrm{OH} \mathrm{D} \mathrm{D}_{3}$ (Han et al., 2012) have high activity at low levels of dietary $\mathrm{Ca}$ and $\mathrm{P}$. Thus, comparing the efficacy of vitamin $\mathrm{D}$ metabolites should be conducted under $\mathrm{Ca}-$ and P-deficient diets. In the present study, the effect of vitamin $\mathrm{D}_{3}$ and $1 \alpha-\mathrm{OH} \mathrm{D}_{3}$ on growth performance and tibia quality was reevaluated on the basis of diets with $0.50 \% \mathrm{Ca}$ and $0.25 \% \mathrm{NPP}$.

The objective of the presented study is to determine the vitamin $D_{3}$ requirement of 1- to 21-dayold broilers fed $\mathrm{Ca}-$ and $\mathrm{P}$-deficient diets and to reevaluate the relative potency of $1 \alpha-\mathrm{OH} \mathrm{D}_{3}$ compared with that of vitamin $\mathrm{D}_{3}$.

\section{Material and methods}

\section{Birds, diets, management}

All procedures used in the present experiment were approved by the Animal Care Committee of Shangqiu Normal University. On the day of hatching, 480 female Ross broilers were individually weighed and randomly assigned to 12 treatments, four cages $(70 \mathrm{~cm} \times 70 \mathrm{~cm} \times 30 \mathrm{~cm})$ with 10 birds per treatment. The lighting system consisted of $23 \mathrm{~h}$ of light from days 0 to 21 . The room temperature was maintained at $33^{\circ} \mathrm{C}$ from days 0 to 3 and then gradually reduced by $3^{\circ} \mathrm{C}$ per week to a final temperature of $24^{\circ} \mathrm{C}$.

Twelve experimental diets were prepared. Vitamin $\mathrm{D}_{3}$ and $1 \alpha-\mathrm{OH} \mathrm{D}_{3}$ were supplied by Tongxiang Tianhecheng Food Technology Co., Ltd. (Jiaxing, China) and Taizhou Healtech Chemical Co., Ltd. (Taizhou, China), respectively. The crystalline vitamin $\mathrm{D}_{3}$ and $1 \alpha-\mathrm{OH} \mathrm{D}_{3}$ were dissolved in ethanol and then brought to final concentrations of $200 \mathrm{mg} \cdot 1^{-1}$ of vitamin $\mathrm{D}_{3}$ and $10 \mathrm{mg} \cdot 1^{-1}$ of $1 \alpha-\mathrm{OH}$ $\mathrm{D}_{3}$ in a solution of $5 \%$ ethanol and $95 \%$ propylene glycol (Han et al., 2009).

The basal diet contained $0.50 \% \mathrm{Ca}, 0.25 \%$ NPP and was without added vitamin $\mathrm{D}_{3}$. It was supplemented with $5,10,25,50,100,250$, 500 and $1000 \mu \mathrm{g} \cdot \mathrm{kg}^{-1}$ of vitamin $\mathrm{D}_{3}$ or 2.5 and $5 \mu \mathrm{g} \cdot \mathrm{kg}^{-1}$ of $1 \alpha-\mathrm{OHD}_{3}$ (Table 1$)$. A diet with adequate

Table 1. Ingredients and nutrient composition of the experimental diets

\begin{tabular}{lcc}
\hline Component & \multicolumn{2}{l}{ Diet $^{3}$} \\
\cline { 2 - 3 } & basal & control \\
\hline Ingredient, $\mathrm{g} \cdot \mathrm{kg}^{-1}$ & & \\
$\quad$ maize & 638.7 & 600.9 \\
soya bean meal & 290.0 & 290.0 \\
soya bean oil & 10.0 & 10.0 \\
lard & 7.2 & 20.5 \\
soya bean protein isolate & 31.3 & 36.5 \\
limestone & 6.9 & 13.9 \\
dicalcium phosphate & 7.2 & 19.5 \\
L-lysine·HCl & 1.8 & 1.8 \\
DL-methionine & 0.6 & 0.6 \\
trace mineral premix ${ }^{1}$ & 1.0 & 1.0 \\
vitamin premix ${ }^{2}$ & 0.3 & 0.3 \\
choline chloride & 2.0 & 2.0 \\
$\quad$ NaCl & 3.0 & 3.0 \\
Nutrient composition & & \\
metabolizable energy, $\mathrm{MJ} \cdot \mathrm{kg}^{-1}$ & 12.55 & 12.55 \\
analysed crude protein, \% & 20.5 & 20.4 \\
analysed calcium, \% & 0.55 & 1.08 \\
analysed total phosphorus, \% & 0.50 & 0.68 \\
calculated non-phytate phosphorus, \% & 0.25 & 0.45 \\
\hline
\end{tabular}

1 the trace-mineral premix provided the following, per kg of diet: $\mathrm{mg}$ : iron 100 , zinc 100 , copper 8 , manganese 120 , iodine 0.7 , selenium $0.3{ }^{2}$ the vitamin premix provided the following, per $\mathrm{kg}$ of diet: IU: vit. A 8000 , vit. E 20; mg: menadione 0.5 , thiamine 2.0 , riboflavin 8.0 , niacin 3.5 , pyridoxine 0.01 ; vit. $B_{12} 0.01$, pantothenic acid 10.0 , folic acid 0.55 , biotin $0.18 ;{ }^{3}$ to the control diet $25 \mu \mathrm{g} \cdot \mathrm{kg}^{-1}$ vit. $\mathrm{D}_{3}$ was added 
levels of $\mathrm{Ca}(1.00 \%), \mathrm{NPP}(0.45 \%)$ and vitamin $\mathrm{D}_{3}$ $\left(25 \mu \mathrm{g} \cdot \mathrm{kg}^{-1}\right)$ was used as the control. The birds were given access to mash diets and water ad libitum during the 21-day experiment.

\section{Sample collection}

On day 21, the broilers were individually weighed. Two chickens were randomly chosen from each replicate for blood and tibia collection. Serum samples $(5 \mathrm{ml})$ were collected using $5 \mathrm{ml}$ anticoagulated syringes (Shanghai K\&G International Co. Ltd., Shanghai, China) by cardiac puncture and then centrifuged for $10 \mathrm{~min}$ at $3000 \mathrm{~g}$ at $20^{\circ} \mathrm{C}$.

The birds were sacrificed by exsanguination, plucked, eviscerated, abdominal fat was removed, and the carcasses were weighed. The left and right tibias were excised and frozen at $-20^{\circ} \mathrm{C}$ for further analysis (breaking strength, ash weight, and content of ash, $\mathrm{Ca}$, and $\mathrm{P}$ ).

\section{Sample analysis}

The $\mathrm{Ca}$ and inorganic phosphate $(\mathrm{Pi})$ in blood serum were immediately determined using a Shimadzu CL-8000 Analyzer (Shimadzu Corp., Kyoto, Japan) following the manufacturer's instructions. According to the method by Hall et al. (2003), the left tibia was boiled for 5 min to loosen the muscle tissue. The meat, connective tissue, and fibula bone were removed from the tibia. The tibia was placed in a container with ethanol for 48 $\mathrm{h}$ to remove water and polar lipids. The bones were then further extracted in anhydrous ether for $48 \mathrm{~h}$ to remove non-polar lipids. The tibias were dried at $105^{\circ} \mathrm{C}$ for $24 \mathrm{~h}$, weighed, and their weight recorded. Tibia ash content was determined by ashing the bone in a muffle furnace for $18 \mathrm{~h}$ at $600^{\circ} \mathrm{C}$.

The right tibia was used to analyse the breaking strength. The tibia breaking strength was determined using an all-digital electronic universal testing machine (Shenzhen Hengen Instrument Co. Ltd., Shenzhen, China). The tibias were cradled on two support points $4 \mathrm{~cm}$ apart. Using a $50 \mathrm{~kg}$ load cell and a crosshead speed of $10 \mathrm{~mm} \cdot \mathrm{min}^{-1}$, the force was applied to the midpoint of the same facet of each tibia (Jendral et al., 2008).

$\mathrm{Ca}$ in diets was determined according to the EDTA titration method. Total P in diets was determined by photometric methods after reaction with ammonium molybdate and ammonium metavanadate. The crude protein content in diets was determined according to the Kjeldhal method on a PN1430 apparatus (Barcelona, Spain).

\section{Statistical analyses}

Replicate means are the experimental units in the statistical analysis. All data were analysed with an ANOVA procedure of SAS software (SAS Institute, 2001). The means were compared with Tukey's test at $p<0.05$. Nonlinear regression analysis was conducted using the PROC NLIN procedure of SAS to estimate the vitamin $\mathrm{D}_{3}$ requirement based on the selected variables, including BWG, serum $\mathrm{Ca}$, tibia ash weight and content, and tibia $\mathrm{Ca}$ and $\mathrm{P}$ contents. The model was: $y=a x^{2}+b x+c$, where $y$ is the response and $x$ is the variable. The relative potencies of $1 \alpha-\mathrm{OH} \mathrm{D}_{3}$ to vitamin $\mathrm{D}_{3}$ were determined by the slope ratio method (Littell et al., 1997). The model is: $y=a+b_{1} x_{1}+b_{2} x_{2}$, where $y$ is the response, $x_{1}$ is vitamin $\mathrm{D}_{3}$, and $x_{2}$ is $1 \alpha-\mathrm{OH} \mathrm{D}$.

\section{Results}

The levels of dietary vitamin $\mathrm{D}_{3}$ and $1 \alpha-\mathrm{OH}$ $\mathrm{D}_{3}$ significantly affected $\mathrm{BWG}$, feed intake (FI), and serum $\mathrm{Ca}$ but did not influence the feed conversion ratio (FCR), slaughter yield (SY), and serum Pi in 1- to 21-day-old broilers (Table 2). BWG and FI responded linearly to vitamin $\mathrm{D}_{3}$ ranging from 0 to $50 \mu \mathrm{g} \cdot \mathrm{kg}^{-1}$ and to $1 \alpha-\mathrm{OH} \mathrm{D}_{3}$ from 0 to $5 \mu \mathrm{g} \cdot \mathrm{kg}^{-1}$. Serum Ca also increased linearly to vitamin $\mathrm{D}_{3}$ ranging from 0 to $10 \mu \mathrm{g} \cdot \mathrm{kg}^{-1}$ and to $1 \alpha-\mathrm{OH} \mathrm{D}_{3}$ from 0 to $5 \mu \mathrm{g} \cdot \mathrm{kg}^{-1}$. Serum Pi in broiler chickens fed $25 \mu \mathrm{g} \cdot \mathrm{kg}^{-1}$ of vitamin $\mathrm{D}_{3}$ was higher than that of birds fed the basal diet $(p<0.05)$. No significant differences. were observed in BWG, FI, or serum Ca among the broilers fed 10 to $1000 \mu \mathrm{g} \cdot \mathrm{kg}^{-1}$ vitamin $\mathrm{D}_{3}$ or $5 \mu \mathrm{g} \cdot \mathrm{kg}^{-1} 1 \alpha-\mathrm{OH} \mathrm{D}_{3}$, and those fed the control diets.

The tibia ash weight of the broilers increased linearly from 0.42 to $0.71 \mathrm{~g}$ /tibia when the dietary vitamin $\mathrm{D}_{3}$ increased from 0 to $100 \mu \mathrm{g} \cdot \mathrm{kg}^{-1}$ (Table $3)$. Tibia ash content $\left(\mathrm{g} \cdot 100 \mathrm{~g}^{-1}\right)$ also enhanced linearly to vitamin $D_{3}$ ranging from 0 to $25 \mu \mathrm{g} \cdot \mathrm{kg}^{-1}$. Broilers fed 25 to $1000 \mu \mathrm{g} \cdot \mathrm{kg}^{-1}$ vitamin $\mathrm{D}_{3}$ achieved a significantly greater tibia breaking strength than the birds fed the basal diet. The content of tibia $\mathrm{Ca}$ and $\mathrm{P}$ in broilers fed $25 \mu \mathrm{g} \cdot \mathrm{kg}^{-1}$ vitamin $\mathrm{D}_{3}$ was significantly higher than that of birds fed the basal diet $(p<0.05)$. The addition of $5 \mu \mathrm{g} \cdot \mathrm{kg}^{-1} 1 \alpha-\mathrm{OH}$ $\mathrm{D}_{3}$ resulted in greater tibia ash weight and content, breaking strength, and $\mathrm{Ca}$ and $\mathrm{P}$ content, compared with the birds fed the basal diet. No significant differences in tibia ash weight, breaking strength, or $\mathrm{Ca}$ and $\mathrm{P}$ contents were observed between the broilers fed with $5 \mu \mathrm{g} \cdot \mathrm{kg}^{-1} 1 \alpha-\mathrm{OH} \mathrm{D}$ or 25 to $1000 \mu \mathrm{g}$ $\cdot \mathrm{kg}^{-1}$ vitamin $\mathrm{D}_{3}$ and the control diets.

Using BWG, serum $\mathrm{Ca}$, tibia ash weight and content, and tibia $\mathrm{Ca}$ and $\mathrm{P}$ contents as the criteria, 
Table 2. Effects of vitamin $\mathrm{D}_{3}$ and $1 \alpha-\mathrm{OH} \mathrm{D}_{3}$ on growth performance of 1 - to 21 -day-old broilers

\begin{tabular}{|c|c|c|c|c|c|c|c|c|}
\hline \multirow{2}{*}{ Group } & \multirow[b]{2}{*}{$\begin{array}{l}D_{3} \\
\mu g \cdot \mathrm{kg}^{-1}\end{array}$} & \multirow[b]{2}{*}{$\begin{array}{l}1 \alpha-\mathrm{OH} \mathrm{D}_{3} \\
\mu \mathrm{g} \cdot \mathrm{kg}^{-1}\end{array}$} & \multicolumn{4}{|l|}{ Growth $^{2}$} & \multicolumn{2}{|l|}{ Serum $^{3}$} \\
\hline & & & $\begin{array}{l}\text { BWG } \\
\mathrm{g} \cdot \text { bird }^{-1}\end{array}$ & $\begin{array}{l}\mathrm{FI} \\
\mathrm{g} \cdot \text { bird }^{-1}\end{array}$ & $\begin{array}{l}\text { FCR } \\
\text { (Fl/BWG) }\end{array}$ & $\begin{array}{l}\text { SY } \\
\%\end{array}$ & $\begin{array}{l}\mathrm{Ca} \\
\mathrm{mg} \cdot 100 \mathrm{ml}^{-1}\end{array}$ & $\begin{array}{l}\mathrm{Pi} \\
\mathrm{mg} \cdot 100 \mathrm{ml}^{-1}\end{array}$ \\
\hline 1 & \multicolumn{2}{|l|}{ Basal diet } & $563^{d}$ & $910^{c}$ & 1.62 & 68.89 & $6.50^{\circ}$ & $5.47^{b}$ \\
\hline 2 & \multicolumn{2}{|l|}{5} & $581^{\mathrm{cd}}$ & $938^{b c}$ & 1.62 & 68.05 & $7.55^{b}$ & $5.83^{a b}$ \\
\hline 3 & \multicolumn{2}{|l|}{10} & $617^{\mathrm{abc}}$ & $1041^{a b}$ & 1.69 & 70.05 & $8.64^{a}$ & $6.11^{\mathrm{ab}}$ \\
\hline 4 & \multicolumn{2}{|l|}{25} & $638^{\mathrm{ab}}$ & $1070^{\mathrm{a}}$ & 1.68 & 69.79 & $8.14^{\mathrm{ab}}$ & $6.75^{\mathrm{a}}$ \\
\hline 5 & \multicolumn{2}{|l|}{50} & $641^{\mathrm{ab}}$ & $1082^{a}$ & 1.69 & 69.10 & $8.20^{\mathrm{ab}}$ & $6.25^{\mathrm{ab}}$ \\
\hline 6 & \multicolumn{2}{|l|}{100} & $634^{\mathrm{ab}}$ & $1052^{a}$ & 1.66 & 69.07 & $8.54^{\mathrm{ab}}$ & $6.41^{\mathrm{ab}}$ \\
\hline 7 & \multicolumn{2}{|l|}{250} & $635^{\mathrm{ab}}$ & $1099^{a}$ & 1.73 & 68.07 & $8.27^{\mathrm{ab}}$ & $6.21^{\mathrm{ab}}$ \\
\hline 8 & \multicolumn{2}{|l|}{500} & $638^{\mathrm{ab}}$ & $1073^{a}$ & 1.68 & 68.95 & $8.53^{\mathrm{ab}}$ & $6.45^{\mathrm{ab}}$ \\
\hline 9 & \multicolumn{2}{|l|}{1000} & $647^{\mathrm{ab}}$ & $1085^{a}$ & 1.68 & 68.67 & $8.41^{\mathrm{ab}}$ & $6.38^{\mathrm{ab}}$ \\
\hline 10 & & 2.5 & $602^{\text {bcd }}$ & $1023^{\mathrm{abc}}$ & 1.70 & 68.86 & $8.36^{\mathrm{ab}}$ & $5.90^{\mathrm{ab}}$ \\
\hline 11 & \multirow{2}{*}{\multicolumn{2}{|c|}{$\begin{array}{r}5.0 \\
\text { Control diet }\end{array}$}} & $618^{a b c}$ & $1041^{\mathrm{ab}}$ & 1.69 & 70.40 & $8.45^{\mathrm{ab}}$ & $5.82^{\mathrm{ab}}$ \\
\hline 12 & & & $648^{a}$ & $1067^{a}$ & 1.65 & 71.83 & $8.69^{a}$ & $6.72^{\mathrm{a}}$ \\
\hline \multicolumn{3}{|l|}{ SEM } & 4 & 10 & 0.01 & 0.25 & 0.10 & 0.08 \\
\hline \multicolumn{3}{|c|}{$P$ value } & $<0.001$ & $<0.001$ & 0.435 & 0.092 & $<0.001$ & 0.012 \\
\hline \multicolumn{3}{|c|}{ Source of variation } & Probabilitie & & & & & \\
\hline \multicolumn{3}{|c|}{ Vitamin $D_{3}$ level } & $<0.001$ & $<0.001$ & 0.392 & 0.669 & $<0.001$ & 0.057 \\
\hline \multicolumn{3}{|c|}{$1 \alpha-\mathrm{OH} \mathrm{D}_{3}$ level } & 0.021 & 0.006 & 0.313 & 0.368 & $<0.001$ & 0.400 \\
\hline
\end{tabular}

a-d means in the same column without a common superscript differ significantly $(p<0.05) ;{ }^{1}$ the basal diet contained $0.50 \%$ Ca and $0.25 \%$ NPP, no added vitamin $\mathrm{D}_{3}$. The control diet contained $1.00 \% \mathrm{Ca}, 0.45 \% \mathrm{NPP}$, and $25 \mu \mathrm{g} \cdot \mathrm{kg}^{-1}$ vitamin $\mathrm{D}_{3}$; BWG - body weight gain, $\mathrm{FI}-$ feed intake, FCR - feed conversion ratio, SY - slaughter yield (carcass weight as a percentage of live body weight), $\mathrm{Ca}$ - calcium, $\mathrm{Pi}$ - inorganic phosphate; ${ }^{2}$ data are means of 4 replicate cages consisting of 10 birds per replicate cage; ${ }^{3}$ data are means of 4 replicates consisting of 2 birds per replicate

Table 3. Effects of vitamin $\mathrm{D}_{3}$ and $1 \alpha-\mathrm{OH} \mathrm{D}_{3}$ on tibia quality of 1 - to 21 -day-old broilers

\begin{tabular}{|c|c|c|c|c|c|c|c|}
\hline Group & $\begin{array}{l}D_{3} \\
\mu \mathrm{g} \cdot \mathrm{kg}^{-1}\end{array}$ & $\begin{array}{l}1 \alpha-\mathrm{OH} \mathrm{D}_{3} \\
\mu \mathrm{g} \cdot \mathrm{kg}^{-1}{ }^{3}\end{array}$ & $\frac{\text { Ash }}{\text { g/tibia }}$ & $\mathrm{g} \cdot 100 \mathrm{~g}^{-1}$ & $\begin{array}{l}\text { Breaking- } \\
\text { - strength, } N\end{array}$ & $\begin{array}{l}\mathrm{Ca} \\
\mathrm{g} \cdot 100 \mathrm{~g}^{-1}\end{array}$ & $\begin{array}{l}P \\
g \cdot 100 g^{-1}\end{array}$ \\
\hline 1 & \multicolumn{2}{|l|}{ Basal diet } & $0.42^{\circ}$ & $40.96^{d}$ & $43.67^{d}$ & $14.12^{\mathrm{b}}$ & $6.73^{b}$ \\
\hline 2 & \multicolumn{2}{|l|}{5} & $0.55^{\mathrm{bc}}$ & $41.34^{\mathrm{cd}}$ & $63.48^{\mathrm{bcd}}$ & $15.13^{a b}$ & $7.39^{\mathrm{ab}}$ \\
\hline 3 & \multicolumn{2}{|l|}{10} & $0.58^{b c}$ & $42.48^{\mathrm{bcd}}$ & $61.13^{\text {cd }}$ & $15.44^{\mathrm{ab}}$ & $7.70^{\mathrm{a}}$ \\
\hline 4 & \multicolumn{2}{|l|}{25} & $0.61^{\mathrm{ab}}$ & $44.05^{\mathrm{ab}}$ & $77.20^{\mathrm{abc}}$ & $16.19^{a}$ & $8.06^{a}$ \\
\hline 5 & \multicolumn{2}{|l|}{50} & $0.65^{\mathrm{ab}}$ & $42.65^{\text {bcd }}$ & $69.45^{\mathrm{abc}}$ & $15.89^{\mathrm{ab}}$ & $7.62^{\mathrm{ab}}$ \\
\hline 6 & \multicolumn{2}{|l|}{100} & $0.71^{\mathrm{ab}}$ & $43.24^{\mathrm{bc}}$ & $78.30^{\mathrm{abc}}$ & $16.15^{a}$ & $7.65^{\mathrm{ab}}$ \\
\hline 7 & \multicolumn{2}{|l|}{250} & $0.66^{\mathrm{ab}}$ & $43.61^{\mathrm{ab}}$ & $73.67^{\mathrm{abc}}$ & $15.16^{\mathrm{ab}}$ & $7.83^{\mathrm{a}}$ \\
\hline 8 & \multicolumn{2}{|l|}{500} & $0.62^{\mathrm{ab}}$ & $42.16^{\mathrm{bcd}}$ & $67.59^{\mathrm{abc}}$ & $15.21^{\mathrm{ab}}$ & $7.70^{\mathrm{a}}$ \\
\hline 9 & \multicolumn{2}{|l|}{1000} & $0.67^{\mathrm{ab}}$ & $43.61^{\mathrm{ab}}$ & $80.54^{\mathrm{abc}}$ & $15.14^{\mathrm{ab}}$ & $7.79^{a}$ \\
\hline \multicolumn{2}{|l|}{10} & 2.5 & $0.67^{\mathrm{ab}}$ & $43.33^{b c}$ & $69.55^{\mathrm{abc}}$ & $15.27^{\mathrm{ab}}$ & $7.54^{\mathrm{ab}}$ \\
\hline \multicolumn{2}{|l|}{11} & 5.0 & $0.69^{\mathrm{ab}}$ & $43.78^{a b}$ & $86.84^{a}$ & $15.98^{a}$ & $7.72^{\mathrm{a}}$ \\
\hline \multicolumn{2}{|l|}{12} & Control diet & $0.77^{\mathrm{a}}$ & $45.57^{a}$ & $82.51^{\mathrm{ab}}$ & $16.49^{a}$ & $8.18^{\mathrm{a}}$ \\
\hline \multicolumn{3}{|l|}{ SEM } & 0.02 & 0.21 & 1.95 & 0.13 & 0.07 \\
\hline \multicolumn{3}{|c|}{$P$ value } & $<0.001$ & $<0.001$ & $<0.001$ & 0.003 & 0.002 \\
\hline \multicolumn{3}{|c|}{ Source of variation } & \multicolumn{5}{|c|}{ Probabilities } \\
\hline \multicolumn{3}{|c|}{ Vitamin $\mathrm{D}_{3}$ level } & $<0.001$ & $<0.001$ & $<0.001$ & 0.003 & 0.008 \\
\hline \multicolumn{3}{|c|}{$1 \alpha-\mathrm{OH} \mathrm{D}_{3}^{3}$ level } & $<0.001$ & 0.002 & $<0.001$ & 0.087 & 0.057 \\
\hline
\end{tabular}

${ }^{a-d}$ means in the same column without a common superscript differ significantly $(p<0.05) ;{ }^{1}$ the basal diet contained $0.50 \%$ Ca and $0.25 \%$ NPP, no added vitamin $\mathrm{D}_{3}$. The control diet contained $1.00 \% \mathrm{Ca}, 0.45 \% \mathrm{NPP}$, and $25 \mu \mathrm{gg} \mathrm{kg}^{-1}$ vitamin $\mathrm{D}_{3}$; data are means of 4 replicates consisting of 2 birds per replicate; $\mathrm{Ca}$ - calcium, $\mathrm{P}$ - phosphorus

Table 4. Vitamin $D_{3}$ requirements of 1 - to 21 -day-old broilers fed Ca- and P-deficient diets

\begin{tabular}{llllr}
\hline Indices & Formula & $\mathrm{P}$ value & $\mathrm{X}, \mathrm{D}_{3}, \mu \mathrm{g} \cdot \mathrm{kg}^{-1}$ & $\mathrm{D}_{3}$ requirement, $\mu \mathrm{g} \cdot \mathrm{kg}^{-1}$ \\
\hline Body weight gain & $y=-0.02050 x^{2}+2.6250 x+574.5$ & $<0.001$ & 0 to 100 & 64.0 \\
Serum calcium & $y=-0.00939 x^{2}+0.3035 x+6.4335$ & $<0.001$ & 0 to 25 & 16.2 \\
Tibia ash weight & $y=-0.00001 x^{2}+0.00346 x+0.5044$ & $<0.001$ & 0 to 250 & 173.0 \\
Tibia ash content & $y=-0.00056 x^{2}+0.0729 x+41.3806$ & 0.002 & 0 to 100 & 65.1 \\
Tibia calcium & $y=-0.00194 x^{2}+0.1283 x+14.3039$ & 0.002 & 0 to 50 & 33.1 \\
Tibia phosphorus & $y=-0.00149 x^{2}+0.0893 x+6.8624$ & 0.003 & 0 to 50 & 30.0 \\
\hline
\end{tabular}


Table 5. Relative potencies of $1 \alpha-\mathrm{OH} \mathrm{D}_{3}$ to vitamin $\mathrm{D}_{3}$ in 1 - to 21 -day-old broilers fed Ca- and P-deficient diets ${ }^{1}$

\begin{tabular}{lllllr}
\hline Indices & Formula & $\mathrm{P}$ value & $x_{1} \mu \mathrm{g} \cdot \mathrm{kg}^{-1}$ & $\mathrm{x}_{2} \mu \mathrm{g} \cdot \mathrm{kg}^{-1}$ & Relative potency \\
\hline Body weight gain & $y=582.1757+1.4412 x_{1}+7.2444 x_{2}$ & $<0.001$ & 0 to 50 & 0 to 5 & 5.03 \\
Serum calcium & $y=6.7471+0.1835 x_{1}+0.4015 x_{2}$ & $<0.001$ & 0 to 10 & 0 to 5 & 2.19 \\
Tibia ash weight & $y=0.5247+0.0021 x_{1}+0.0378 x_{2}$ & $<0.001$ & 0 to 100 & 0 to 5 & 18.00 \\
Tibia ash content & $y=41.1253+0.1170 x_{1}+0.6018 x_{2}$ & $<0.001$ & 0 to 25 & 0 to 5 & 5.14 \\
Tibia calcium & $y=14.4813+0.0740 x_{1}+0.3025 x_{2}$ & 0.006 & 0 to 25 & 0 to 5 & 4.09 \\
Tibia phosphorus & $y=7.0305+0.0456 x_{1}+0.1518 x_{2}$ & 0.003 & 0 to 25 & 0 to 5 & 3.33 \\
\hline
\end{tabular}

${ }^{1} x_{1}=\mathrm{D}_{3}, \mathrm{x}_{2}=1 \alpha-\mathrm{OH} \mathrm{D}_{3}$

the vitamin $\mathrm{D}_{3}$ requirements of 1- to 21-day-old broilers fed $\mathrm{Ca}-$ and P-deficient diets were 64.0, $16.2,173.0,65.1,33.1$ and $30.0 \mu \mathrm{g} \cdot \mathrm{kg}^{-1}$ (Table 4), and the relative potencies of $1 \alpha-\mathrm{OH} \mathrm{D}_{3}$ to vitamin $\mathrm{D}_{3}$ were $5.03,2.19,18.00,5.14,4.09$ and 3.33 , respectively (Table 5).

\section{Discussion}

The addition of $60 \mu \mathrm{g} \cdot \mathrm{kg}^{-1}$ of vitamin $\mathrm{D}_{3}$ increased the BWG of broilers fed with $\mathrm{Ca}$ - and $\mathrm{P}$ deficient diets, reaching levels similar to those of birds fed control diets (Rao et al., 2006). Driver et al. (2005) also found that Ca- and P-deficient broilers fed $1 \alpha-\mathrm{OH} \mathrm{D}_{3}$ and phytase had equal growth performance and tibia ash weight compared with birds fed diets with adequate $\mathrm{Ca}$ and $\mathrm{P}$. In the present study, no significant difference was observed in the growth rate as well as ash weight, breaking strength, and $\mathrm{Ca}$ and $\mathrm{P}$ contents of the tibia among the broilers fed 25 to $1000 \mu \mathrm{g} \cdot \mathrm{kg}^{-1}$ vitamin $\mathrm{D}_{3}$ and those fed the control diets.

Phosphorous deficiency reduces carcass weight (Angel et al., 2006) and yield in broilers (Chen and Moran, 1995). When phytase was added, the carcass yield increased (Pillai et al., 2006). By contrast, the slaughter yield of the broilers was not significantly affected by the supplementation of vitamin $\mathrm{D}_{3}$ or $1 \alpha-\mathrm{OH} \mathrm{D}$ in the present experiment. Scheideler and Ferket (2000) also found that the dietary P levels (NPP 0.30 vs. $0.42 \%$ ) did not influence the weight of the carcass, thigh and breast meat of the broilers.

Dietary vitamin $\mathrm{D}_{3}$ (Rao et al., 2006), 1,25$(\mathrm{OH})_{2} \mathrm{D}_{3}$ (Edwards, 2002), and $1 \alpha-\mathrm{OH} \mathrm{D}$ (Edwards et al., 2002; Han et al., 2009) increased the serum $\mathrm{Ca}$ and $\mathrm{Pi}$ concentrations in broilers. In contrast, Driver et al. (2008) reported that $1 \alpha-\mathrm{OH} \mathrm{D}$ did not affect the serum Pi content in non-obese diabetic mice. In the present study, the increase of dietary vitamin $\mathrm{D}_{3}$ enhanced serum $\mathrm{Ca}$ and $\mathrm{Pi}$ contents, whereas serum $\mathrm{P}$ did not depend on the $1 \alpha-\mathrm{OH} \mathrm{D} \mathrm{D}_{3}$ level.

Studies have shown that vitamin $\mathrm{D}_{3}$ (Rao et al., 2009), $1 \alpha-\mathrm{OH} \mathrm{D_{3 }}$ (Snow et al., 2004),
25-OH D $\mathrm{D}_{3}$ (Aburto et al., 1998) and 1,25-(OH)2 $\mathrm{D}_{3}$ (Edwards, 2002) increase bone weight, length, and ash in broilers. These data indicate that vitamin D metabolites increase bone growth and mineral deposition in poultry. Fritts and Waldroup (2003) reported no significant differences in tibia ash weight among the broilers fed 25, 50 and $100 \mu \mathrm{g} \cdot \mathrm{kg}^{-1}$ vitamin $\mathrm{D}_{3}$. Similar results were found in the present experiment. When the vitamin $\mathrm{D}_{3}$ level ranged from 25 to $1000 \mu \mathrm{g} \cdot \mathrm{kg}^{-1}$, no significant differences were observed in tibia ash weight, breaking strength, and $\mathrm{Ca}$ and $\mathrm{P}$ contents of the tibia of the broilers.

The NRC (1994) recommendation on vitamin $\mathrm{D}_{3}$ for broilers is $5 \mu \mathrm{g} \cdot \mathrm{kg}^{-1}$ in Ca- and P-adequate diets, which may be lower than the practical requirement. Research has shown that about 25 and $50 \mu \mathrm{g} \cdot \mathrm{kg}^{-1}$ of vitamin $\mathrm{D}_{3}$ were needed to maximize the body weight and bone ash of 42-day-old broilers, respectively (Fritts and Waldroup, 2003). When broilers were fed with $\mathrm{Ca}$ - and P-deficient diets, the addition of $1250 \mu \mathrm{g} \cdot \mathrm{kg}^{-1}$ vitamin $\mathrm{D}_{3}$ resulted in greater tibia ash than the addition of 0 and $37.5 \mu \mathrm{g} \cdot \mathrm{kg}^{-1}$ of vitamin $\mathrm{D}_{3}$ (Baker et al., 1998). The addition of $6660 \mu \mathrm{g} \cdot \mathrm{kg}^{-1}$ vitamin $\mathrm{D}_{3}$ yielded higher toe ash contents and $\mathrm{Ca}$ and $\mathrm{P}$ retention than the addition of 66 and $660 \mu \mathrm{g} \cdot \mathrm{kg}^{-1}$ of vitamin $\mathrm{D}_{3}$ (Qian et al., 1997). At $42 \mathrm{~d}$, the body weight of broilers fed $100 \mu \mathrm{g} \cdot \mathrm{kg}^{-1}$ of vitamin $\mathrm{D}_{3}$ was significantly greater than of birds fed 25 or $50 \mu \mathrm{g} \cdot \mathrm{kg}^{-1}$ (Fritts and Waldroup, 2005). These data suggest that the vitamin $\mathrm{D}_{3}$ requirements of broilers in the Caand P-deficient diets were more than those of the birds fed Ca- and P-adequate diets. Rao et al. (2009) reported, however, that the vitamin $\mathrm{D}_{3}$ requirements of broilers fed $\mathrm{Ca}$ - and P-deficient diets ranged from 16 to $25 \mu \mathrm{g} \cdot \mathrm{kg}^{-1}$. This value may be lower than the actual requirement. Using weight gain and tibia ash weight and content as the criteria in the present experiment, we found that the vitamin $\mathrm{D}_{3}$ requirements were $64.0,173.0$ and $65.1 \mu \mathrm{g} \cdot \mathrm{kg}^{-1}$ in broilers fed $\mathrm{Ca}$ - and P-deficient diets, respectively.

Previous research has shown that $1 \alpha-\mathrm{OH} \mathrm{D}_{3}$ is 4.5 times more active than vitamin $\mathrm{D}_{3}$ in respect to the BWG of broiler chickens (Soares et al., 1978), 
8.6 times in respect to tibia ash increase (Boris et al., 1977), and at least 10 times in terms of mobilizing bone calcium and raising plasma calcium concentrations in Leghorn cockerels (Haussler et al., 1973). Using body weight, plasma Ca, tibia ash weight and percentage, and incidence of rickets as criteria, Edwards et al. (2002) reported that the relative biological values of $1 \alpha-\mathrm{OH} \mathrm{D}_{3}$ to vitamin $\mathrm{D}_{3}$ were $10.08,9.50,11.26,4.48$, and 4.50 , respectively. The relative potency of $1 \alpha-\mathrm{OH} \mathrm{D}_{3}$ to vitamin $\mathrm{D}_{3}$ on body weight in our study was similar to the results of Soares et al. (1978) and lower in BWG and plasma $\mathrm{Ca}$, whereas higher in tibia ash weight and content, than those reported by Edwards et al. (2002). The differences may have been caused by the age and sex of the birds and the dietary $\mathrm{Ca}$ and $\mathrm{P}$ contents. Edwards et al. (2002) used 1- to 16-day-old mixed-sex broilers fed 1.0\% $\mathrm{Ca}$ and $0.7 \% \mathrm{tP}$, whereas the present experiment used 1- to 21 -day-old female birds fed $0.50 \% \mathrm{Ca}$ and $0.48 \%$ tP. Our results are in accordance with other studies where the relative efficacy of $1 \alpha-\mathrm{OH}$ $\mathrm{D}_{3}$ to vitamin $\mathrm{D}_{3}$ in terms of tibia ash weight was higher than for body weight.

\section{Conclusions}

Dietary vitamin $\mathrm{D}_{3}$ and $1 \alpha-\mathrm{OH} \mathrm{D}_{3}$ improved growth performance and serum $\mathrm{Ca}$ as well as the tibia quality of broiler chickens. Using BWG, serum $\mathrm{Ca}$, tibia ash weight and content, and tibia $\mathrm{Ca}$ and $\mathrm{P}$ contents as the criteria, the vitamin $\mathrm{D}_{3}$ requirements of 1- to 21-day-old broilers fed Ca- and Pdeficient diets were 64.0, 16.2, 173.0, 65.1, 33.1 and $30.0 \mu \mathrm{g} \cdot \mathrm{kg}^{-1}$, and the relative potencies of $1 \alpha-\mathrm{OH}$ $\mathrm{D}_{3}$ to vitamin $\mathrm{D}_{3}$ were $5.03,2.19,18.00,5.14,4.09$ and 3.33, respectively. These data indicate that high levels of vitamin $\mathrm{D}_{3}$ can spare the use of $\mathrm{P}$ in broiler diets and that the potency of $1 \alpha-\mathrm{OH} \mathrm{D}_{3}$ is higher than that of vitamin $\mathrm{D}_{3}$.

\section{Acknowledgements}

Supported by the National Natural Science Foundation of China (No. 31101732) and the Natural Science Foundation of Henan Province (No. 2011B230011).

\section{References}

Aburto A., Jr Edwards H.M., Britton W.M., 1998. The influence of vitamin $A$ on the utilization and amelioration of toxicity of cholecalciferol, 25-hydroxycholecalciferol, and 1,25-dihydroxycholecalciferol in young broiler chickens. Poultry Sci. $77,585-593$
Angel R., Saylor W.W., Mitchell A.D., Powers W., Applegate T.J., 2006. Effect of dietary phosphorus, phytase, and 25-hydroxycholecalciferol on broiler chicken bone mineralization, litter phosphorus, and processing yields. Poultry Sci. 85, 1200-1211

Baker D.H., Biehl R.R., Emmert J.L., 1998. Vitamin D requirement of young chicks receiving diets varying in calcium and available phosphorus. Brit. Poultry Sci. 39, 413-417

Boris A., Hurley J.F., Trmal T., 1977. Relative activities of some metabolites and analogs of cholecalciferol in stimulation of tibia ash weight in chicks otherwise deprived of vitamin D. J. Nutr. 107, 194-198

Chen X., Jr. Moran E.T., 1995. The withdrawal feed of broilers: Carcass responses to dietary phosphorus. J. Appl. Poultry Res. 4, 69-82

Driver J.P., Foreman O., Mathieu C., van Etten E., Serreze D.V., 2008. Comparative therapeutic effects of orally administered 1,25-dihydroxyvitamin $\mathrm{D}_{3}$ and 1alpha-hydroxyvitamin $\mathrm{D}_{3}$ on type-1 diabetes in non-obese diabetic mice fed a normalcalcaemic diet. Clin. Exp. Immunol. 151, 76-85

Driver J.P., Pesti G.M., Bakalli R.I., Edwards H.M. Jr., 2005. Phytase and 1a-hydroxycholecalciferol supplementation of broiler chickens during the starting and growing/finishing phases. Poultry Sci. 84, 1616-1628

Edwards Jr. H.M., 2002. Studies on the efficacy of cholecalciferol and derivatives for stimulating phytate utilization in broilers. Poultry Sci. 81, 1026-1031

Edwards Jr. H.M., Shirley R.B., Escoe W.B., Pesti G.M., 2002. Quantitative evaluation of 1a-hydroxycholecalciferol as a cholecalciferol substitute for broilers. Poultry Sci. 81, 664-669

Fritts C.A., Waldroup P.W., 2003. Effect of source and level of vitamin $\mathrm{D}$ on live performance and bone development in growing broilers. J. Appl. Poultry Res. 12, 45-52

Fritts C.A., Waldroup P.W., 2005. Comparison of cholecalciferol and 25-hydroxycholecalciferol in broiler diets designed to minimize phosphorus excretion. J. Appl. Poultry Res. 14, 156-166

Hall L.E., Shirley R.B., Bakalli R.I., Aggrey S.E., Pesti G.M., Edwards Jr. H.M., 2003. Power of two methods for the estimation of bone ash of broilers. Poultry Sci. 82, 414-418

Han J.C., Liu Y., Yao J.H., Wang J.Q., Qu H.X., Yan Y.F., Yue J., Ding J.L., Shi Z.T., Dong X.S., 2012. Dietary calcium levels reduce the efficacy of one alpha-hydroxycholecalciferol in phosphorus-deficient diets of broilers. J. Poultry Sci. 49, 34-38

Han J.C., Yang X.D., Zhang T., Li H., Li W.L., Zhang Z.Y., Yao J.H., 2009. Effects of 1a-hydroxycholecalciferol on growth performance, parameters of tibia and plasma, meat quality, and type llb sodium phosphate cotransporter gene expression of one- to twenty-one-day-old broilers. Poultry Sci. 88, 323-329

Haussler M.R., Zerwekh J.E., Hesse R.H., Rizzardo E., Pechet M.M., 1973. Biological activity of la-hydroxycholecalciferol, a synthetic analog of the hormonal form of vitamin $\mathrm{D}_{3}$. Proc. Nat. Acad. Sci. USA. 70, 2248-2252

Jendral M.J., Korver D.R., Church J.S., Feddes J.J.R., 2008. Bone mineral density and breaking strength of white leghorns housed in conventional, modified, and commercially available colony battery cages. Poultry Sci. 87, 828-837

Kasim A.B., Edwards Jr. H.M. Jr., 2000. Evaluation of cholecalciferol sources using broiler chick bioassays. Poultry Sci. 79 , 1617-1622

Kim W.K., Bloomfield S.A., Ricke S.C., 2011. Effects of age, vitamin $\mathrm{D}_{3}$, and fructooligosaccharides on bone growth and skeletal integrity of broiler chicks. Poultry Sci. 90, 2425-2432

Littell R.C., Henry P.R., Lewis A.J., Ammerman C.B., 1997. Estimation of relative bioavailability of nutrients using SAS procedures. J. Anim. Sci. 75, 2672-2683 
Pillai P.B., O'Connor-Dennie T., Owens C.M., Emmert J.L., 2006. Efficacy of an Escherichia coli phytase in broilers fed adequate or reduced phosphorus diets and its effect on carcass characteristics. Poultry Sci. 85, 1737-1745

Qian H., Kornegay E.T., Denbow D.M., 1997. Utilization of phytate phosphorus and calcium as influenced by microbial phytase, cholecalciferol, and the calcium total phosphorus ratio in broiler diets. Poultry Sci. 76, 37-46

Rao S.V.R., Raju M.V.L.N., Panda A.K., Shyam Sunder G., Sharma R.P., 2006. Effect of high concentrations of cholecalciferol on growth, bone mineralization and mineral retention in broiler chicks fed suboptimal concentrations of calcium and non-phytate phosphorus. J. Appl. Poultry Res. 131, 135-150

Rao S.V.R., Raju M.V.L.N.,Panda A.K., Shyam Sunder G., Sharma R.P., 2009. Performance and bone mineralisation in broiler chicks fed on diets with different concentrations of cholecalciferol at a constant ratio of calcium to non-phytate phosphorus. Brit. Poultry Sci. 50, 528-535

SAS, 2001. SAS/STAT User's Guide. Release 8.2. Stat. Anal. Syst. SAS Institute Inc. Cary, NC
Scheideler S.E., Ferket P.R., 2000. Phytase in broiler rations-effects on carcass yields and incidence of tibial dyschondroplasia. J. Appl. Poultry Res. 9, 468-475

Snow J.L., Baker D.H., Parsons C.M., 2004. Phytase, citric acid, and 1a-hydroxycholecalciferol improve phytate phosphorus utilization in chicks fed a corn-soybean meal diet. Poultry Sci. 83, 1187-1192

Soares J.H. Jr., Swerdel M.R., Bossard E.H., 1978. Phosphorusavailability. 1. The effect of chick age and vitamin D metabolites on the availability of phosphorus in defluorinated phosphate. Poultry Sci. 57, 1305-1312

Whitehead C.C., McCormack H.A., McTeir L., Fleming R.H., 2004. High vitamin $D_{3}$ requirements in broilers for bone quality and prevention of tibial dyschondroplasia and interactions with dietary calcium, available phosphorus and vitamin A. Brit. Poultry Sci. 45, 425-436

Yarger J.G., Saunders C.A., McNaughton J.L., Quarles C.L., Hollis B.W., Gray R.W., 1995. Comparison of dietary 25-hydroxycholecalciferol and cholecalciferol in broiler chickens. Poultry Sci. $74,1159-1167$ 